\title{
Three New Amides from Streptomyces sp. $\mathrm{H} 7372$
}

\author{
Sarot Cheenpracha, ${ }^{a}$ Robert P. Borris, ${ }^{a}$ Tammy T. Tran, ${ }^{a}$ Jap Meng Jee, ${ }^{b}$ \\ Heng Fong Seow, ${ }^{b}$ Hwen-Yee Cheah, ${ }^{b}$ Coy Choke Ho ${ }^{c}$ and Leng Chee Chang ${ }^{*, a}$ \\ ${ }^{a}$ Department of Pharmaceutical Sciences, College of Pharmacy, University of Hawaii Hilo, 34 \\ Rainbow Drive, 96720 Hilo, HI, USA \\ ${ }^{b}$ Immunology Unit, Department of Pathology, Faculty of Medicine and Health Sciences, \\ Universiti Putra Malaysia, 43400 Serdang, Selangor, Malaysia \\ 'Biotechnology Program, School of Science and Technology, University Malaysia Sabah, 88999 \\ Kota Kinabalu, Sabah, Malaysia
}

\begin{abstract}
As amidas fenatato de metila (1), actifenamida (2) e 1- $\beta$-D-glucopiranosídeo-actinofenol (3), juntamente com outros 13 compostos de estruturas conhecidas, foram isolados do extrato de uma cultura de Streptomyces sp H7372. As estruturas destes compostos foram determinadas por análises de RMN uni e bidimensionais e por espectrometria de massas. Cicloheximida (6) e ciclo ( $\Delta$ Ala-L-Val) (8) apresentaram forte atividade inibitória na interação entre Ras-Raf-1 pela técnica de duplo híbrido em leveduras, com halos de inibição de 10 e $25 \mathrm{~mm}$ em SD His ${ }^{-}$, respectivamente, enquanto foram inativos em SD His ${ }^{+}$, na concentração de $25 \mu \mathrm{g} /$ disco.
\end{abstract}

Three new amides, methyl phenatate A (1), actiphenamide (2) and actiphenol 1- $\beta$-Dglucopyranoside (3), along with thirteen known compounds, were isolated from the organic extract of a fermentation culture of Streptomyces sp. H7372. The structures were elucidated by spectroscopic methods including 1D- and 2D-NMR techniques, and MS analyses. Cycloheximide (6) and cyclo( $\Delta$ Ala-L-Val) (8) gave a clear zone of inhibition of Ras-Raf-1 interaction in the yeast twohybrid assay which showed high potency with 10 and $25 \mathrm{~mm}$ clear ZOIs on SD His ${ }^{-}$and inactive on $\mathrm{SD} \mathrm{His}^{+}$at $2.5 \mu \mathrm{g}$ per disk, respectively.

Keywords: Streptomyces sp., yeast two-hybrid screen, Ras-Raf-1 interaction, amides, Cyclo( $(\Delta$ Ala-L-Val $)$

\section{Introduction}

Protein kinases constitute an important group of enzymes that are essential in many physiological processes. Protein phosphorylation is one of the major regulatory mechanisms involved in signal transduction pathways including apoptosis, cell proliferation, cell differentiation, and metabolism. ${ }^{1}$ Abnormalities in protein phosphorylation are often associated with human diseases. Thus, the inhibitors of both protein kinases and phosphatases appear to be very promising drug targets in the chemotherapeutic treatment of cancer and have received wide attention. ${ }^{1}$ The Ras family GTPases play a central role in the growth factor signaling controlling cell proliferation, differentiation, and survival. ${ }^{2}$ The interaction of activated Ras with Raf

*e-mail: lengchee@ hawaii.edu initiates signaling cascades that contribute to a significant percentage of human tumors, suggesting that agents that specifically disrupt this interaction might have desirable chemotherapeutic properties. Recently, the approval of NEXAVAR $^{\circledR}$ (sorafenib) by the FDA for advanced renal cell carcinoma provides justification for the development of Ras-Raf-1 kinase inhibitors. Radicicol, is a macrocyclic antibiotic isolated from the fungus Monosporium bonorden that inhibits the Ras-Raf-1 protein interaction at concentrations of $0.1 \mathrm{ca} .1 \mu \mathrm{g} \mathrm{mL}{ }^{-1}{ }^{3}$ To identify such inhibitors, we employed the yeast two-hybrid system in our screening. ${ }^{3}$

The actinomycete family continues to be a rich reservoir of microorganisms that produce a diverse array of biologically active metabolites effective against a broad spectrum of health problems. For example, staurosporine from Streptomyces staurosporeus exhibited potent inhibition 
of protein kinase $\mathrm{C}$ and also showed antimicrobial activity against fungi and yeast. ${ }^{4}$ As part of an ongoing search for novel protein phosphorylation inhibitors, Streptomyces sp. H7372, a novel strain isolated from a mangrove soil of Sabah, Borneo, Malaysia, was studied. This strain was identified based on the 16S rRNA gene sequence analysis and is a member of the phylogenetically diverse genus Streptomyces. The $n$-BuOH-soluble extract of fermentation cultures of Streptomyces sp. H7372 was found to disrupt Ras-Raf-1 interaction in the yeast two hybrid assay. ${ }^{5} \mathrm{We}$ report herein the isolation, structure elucidation, and biological activities of 1-14.

\section{Experimental}

\section{General experimental procedures}

The optical rotation $[\alpha]_{D}$ values were determined with an Autopol ${ }^{\circledR}$ IV Automatic polarimeter. UV spectra were measured on a Shimadzu PharmaSpec-1700 UV-Visible spectrophotometer. IR spectra were recorded on a Shimadzu-8400S FT-IR spectrometer. Mass spectra and high-resolution MS spectra were taken with a BioTOF II ESI mass spectrometer. 1D and 2D NMR spectra were recorded in chloroform- $d$ and methanol- $d_{4}$ on an INOVA Unity $(500 \mathrm{MHz})$ Varian spectrometer equipped with an xyz-shielded gradient triple resonance probe. Reversed-phase HPLC was carried out on a Beckman Coulter Gold-168 system equipped with a photodiode array detector using an Alltech semipreparative Econosil $\mathrm{C}_{18}$ column $(10 \mu \mathrm{m}, 10 \times 250 \mathrm{~mm})$ run with a flow rate of $2.0 \mathrm{~mL} \mathrm{~min}^{-1}$. Column chromatography (CC) was carried out on Merck silica gel 60 (70-230 mesh). Precoated plates of silica gel $60 \mathrm{~F}_{254}$ were used for analytical purposes.

\section{Microbial material and sample collection}

The organism was isolated from mud sample ( $\mathrm{pH} 7.30)$ under the root of Bruguiera sp., located at sea shore near mouth of river into mangrove swamp, Kampung Termunong, Tuaran, Sabah, Malaysia in 2003. ${ }^{5}$ The strain was isolated by suspending $0.1 \mathrm{~g}$ of soil into $10 \mathrm{~mL}$ of sterile distilled water and later diluting this up to $10^{-3}$. One hundred- $\mu \mathrm{L}$ of the suspension is spread on humic-acid (HV)-vitamins B plus cycloheximide, ${ }^{6}$ with $\mathrm{pH}$ 7.2. Isolated strains were transferred from $\mathrm{HV}$ medium onto similar $\mathrm{pH}$ oatmeal agar plates and incubated at $28^{\circ} \mathrm{C}$ for 14 days until sporulation. The strain $\mathrm{H} 7372$ was characterized by microscopy and determination of cell wall DAP (meso or LL). It was further characterized by $16 \mathrm{~S}$ rRNA gene analysis. A pure culture of strain $\mathrm{H} 7372$ was deposited in National Measurement of Australia and was given an accession number V07/019103. Frozen spore stock of Streptomyces sp. H7372 was stored in $20 \%$ glycerol at $-78^{\circ} \mathrm{C}$. The vial was thawed and spores spread on an ISP4 plate for complete sporulation.

\section{Seed medium}

The composition of the seed medium $\left(20 \mathrm{~g} \mathrm{~L}^{-1}\right.$ of D-mannitol, $20 \mathrm{~g} \mathrm{~L}^{-1}$ of peptone, and $10 \mathrm{~g} \mathrm{~L}^{-1}$ of dextrose) was prepared with distilled water, and the $\mathrm{pH}$ was adjusted to 7.0 prior to sterilization. The medium was dispensed at $50 \mathrm{~mL}$ per $250 \mathrm{~mL}$ in Belco baffled shaker flasks. A single colony from the agar plate was used as inoculum into each flask of mannitol-peptone media, cultured at $30{ }^{\circ} \mathrm{C}$ at $250 \mathrm{rpm}$ for two days.

\section{Production medium}

An aliquot (1\%) from the seed medium was inoculated into the production medium. The composition of the production medium was similar to that of the seed medium. The production cultures were incubated at $30^{\circ} \mathrm{C}$ at $250 \mathrm{rpm}$ for seven days and were then harvested. The supernatants were filtered and partitioned with $n$ - $\mathrm{BuOH}$ three times. Both the $n-\mathrm{BuOH}$-soluble and aqueous layers were tested against the yeast two-hybrid assay.

\section{Extraction and isolation}

The culture broth of Streptomyces sp. H7372 (120 L) was centrifuged, and the supernatant was extracted with $n$-BuOH. An organic extract was suspended in $\mathrm{H}_{2} \mathrm{O}(1: 1)$ then partitioned successively with $\mathrm{CHCl}_{3}$, and EtOAc $\left(3 \times 250 \mathrm{~mL}\right.$ each). The $\mathrm{CHCl}_{3}$ and EtOAc-soluble fractions of the $n-\mathrm{BuOH}$ extract of fermented Streptomyces sp. H7372, exhibited significant activity in the yeast two-hybrid assay at a concentration of $80 \mu \mathrm{g}$ per disk with 21 and $27 \mathrm{~mm}$ zones of inhibition, respectively, and were subjected to bioassay-guided fractionation. The $\mathrm{CHCl}_{3}$ extract $(22.5 \mathrm{~g})$ was fractionated by $\mathrm{CC}$ eluting with hexanes and increasing polarity with acetone and $\mathrm{MeOH}$, successively, to give four fractions (C1-C4). Fraction C2 (2.35 g) was further purified by $\mathrm{CC}$ eluting with $\mathrm{MeOH}-\mathrm{CHCl}_{3}$ (3:97) to afford compound $7(2.9 \mathrm{mg})$. Fraction C3 $(580.5 \mathrm{mg})$ was recrystallized with $\mathrm{MeOH}-\mathrm{CHCl}_{3}(1: 1)$ to give compound $8(32.2 \mathrm{mg})$ and the mother liquor $(528.0 \mathrm{mg})$ was further separated by $\mathrm{CC}$ eluting with $\mathrm{MeOH}-\mathrm{CHCl}_{3}$ (1:99) and followed by RP-18 HPLC with $\mathrm{MeOH}-\mathrm{H}_{2} \mathrm{O}$ (3:1) to give compounds $\mathbf{1 0}\left(12.0 \mathrm{mg}, t_{\mathrm{R}} 17.6 \mathrm{~min}\right)$ and $6\left(4.4 \mathrm{mg}, t_{\mathrm{R}} 20.2 \mathrm{~min}\right)$. The EtOAc extract $(25.8 \mathrm{~g})$ was 
chromatographed sequentially on silica gel eluting with hexanes and increasing polarity with EtOAc and $\mathrm{MeOH}$, respectively, to give nine fractions (B1-B9). Fraction B3 $(1.2 \mathrm{~g})$ was chromatographed over sephadex LH-20 with $\mathrm{MeOH}: \mathrm{H}_{2} \mathrm{O}(7: 3)$ to provide three subfractions (B3a-B3c). Recrystallization of subfraction $\mathrm{B} 3 \mathrm{a}\left(\mathrm{MeOH}: \mathrm{H}_{2} \mathrm{O}, 7: 3\right)$ with $\mathrm{MeOH}: \mathrm{CHCl}_{3}$ (3:97) gave compound 4 (140.3 mg), while subfraction $\mathrm{B} 3 \mathrm{~b}$ (10.4 mg) was purified with preparative TLC with $\mathrm{MeOH}: \mathrm{CHCl}_{3}$ (1:49) to give compound $\mathbf{1}$ (3.4 mg). Compound 9 (20.2 mg) was recrystallized from fraction $\mathrm{B} 5\left(\mathrm{MeOH}-\mathrm{H}_{2} \mathrm{O}, 7: 3\right)$ with $\mathrm{MeOH}: \mathrm{CHCl}_{3}$ (3:97). Fraction B6 (1.58 g) was isolated by $\mathrm{CC}$ eluting with hexanes:EtOAc (3:7) to give compound $\mathbf{5}(3.5 \mathrm{mg})$ and $\mathbf{1 1}$ (110.3 mg) 14 (3.2 mg). Fraction B7 (2.7 g) was purified by $\mathrm{CC}$ eluting with $\mathrm{CHCl}_{3}$ and increasing polarity with $\mathrm{MeOH}$ to afford six subfractions (B7a-B7f). Subfractions B7b, B7c and B7f were isolated by RP-18 HPLC with $\mathrm{MeCN}_{2} \mathrm{H}_{2} \mathrm{O}$ (1:3) to give compounds 12 (4.4 $\left.\mathrm{mg}, t_{\mathrm{R}} 17.5 \mathrm{~min}\right), \mathbf{1 3}$ $\left(1.5 \mathrm{mg}, t_{\mathrm{R}} 18.1 \mathrm{~min}\right)$, and 2 (2.6 mg, $\left.t_{\mathrm{R}} 23.9 \mathrm{~min}\right)$. Fraction B8 $(1.07 \mathrm{~g})$ was purified by CC eluting with $\mathrm{MeOH}: \mathrm{CHCl}_{3}$ (1:9) to provide compound $\mathbf{3}(7.0 \mathrm{mg})$.

\section{Methyl phenatate A (1)}

Colorless viscous oil, $[\alpha]_{D}^{22}-18.8$ (c 0.01, MeOH); UV (MeOH) $\lambda_{\text {max }} / \mathrm{nm}: 207$ (log ع 3.16), 262 (2.75), 348 (2.45); IR (neat) $v_{\max } / \mathrm{cm}^{-1}: 3450,1645 ;{ }^{1} \mathrm{H}$ and ${ }^{13} \mathrm{C} \mathrm{NMR}\left(\mathrm{CDCl}_{3}\right.$, $500 \mathrm{MHz}$ ) data: see Table 1; HRESIMS m/z 308.1501 $[\mathrm{M}+\mathrm{H}]^{+}$(calc. for $\mathrm{C}_{16} \mathrm{H}_{22} \mathrm{NO}_{5}, 308.1498$ ).

\section{Actiphenamide (2)}

Colorless viscous oil, $[\alpha]_{D}^{22}-29.7$ (c 0.01, MeOH); UV (MeOH) $\lambda_{\text {max }} / \mathrm{nm}: 206$ (log $\left.\varepsilon 3.38\right), 218$ (3.28), 282 (2.74); IR (neat) $\mathrm{v}_{\max } / \mathrm{cm}^{-1}: 3405,1660 ;{ }^{1} \mathrm{H}$ and ${ }^{13} \mathrm{C} \mathrm{NMR}\left(\mathrm{CD}_{3} \mathrm{OD}\right.$, $500 \mathrm{MHz}$ ) data: see Table 1; HRESIMS m/z 276.1232 $\left[\mathrm{M}+\mathrm{H}-\mathrm{H}_{2} \mathrm{O}\right]^{+}$(calc. for $\mathrm{C}_{15} \mathrm{H}_{20} \mathrm{NO}_{5}, 276.1230$ ).

\section{Actiphenol 1- $\beta$-D-glucopyranoside (3)}

Colorless viscous oil, $[\alpha]_{D}^{22}+19.1$ (c 0.01, MeOH); UV (MeOH) $\lambda_{\text {max }} / \mathrm{nm}: 207$ (log $\varepsilon$ 4.33), 242 (3.67), 282 (3.25); IR (neat) $v_{\max } / \mathrm{cm}^{-1}: 3400,1690,1253,1055 ;{ }^{1} \mathrm{H}$ and ${ }^{13} \mathrm{C}$ NMR (CD $\left.\mathrm{OD}, 500 \mathrm{MHz}\right)$ data: see Table 1; HRESIMS $m / z 461.1629[\mathrm{M}+\mathrm{H}+\mathrm{Na}]^{+}\left(\right.$calc. for $\mathrm{C}_{21} \mathrm{H}_{28} \mathrm{NO}_{9} \mathrm{Na}$, 461.1662).

\section{Yeast two-hybrid assay}

The inhibition of yeast two-hybrid assay in Saccharomyces cerevisiae was performed as previously described. $^{2}$ The LZ strain, H10014 of the genotype MATa trp1 leu2 his3 LYS: lexA-HIS3 URA3: lexA-lacZ [pLexA$\mathrm{RAS}^{\mathrm{V} 12}$ and pVP16-RAF] was grown on the SD medium agar plate lacking histidine for the generation of stock plate. These cells were grown in the SD medium lacking histidine at $30{ }^{\circ} \mathrm{C}, 220 \mathrm{rpm}$, for 2 days. Four hundred microliters of this culture were inoculated into $100 \mathrm{~mL}$ of medium containing $1 \%$ agar supplemented with $\left(\mathrm{His}^{+}\right)$or without (His $\left.{ }^{-}\right) 130 \mu \mathrm{mol} \mathrm{L}{ }^{-1}$ histidine. Compounds of known concentration dissolved in $\mathrm{MeOH}$ were dispensed onto disks in $20 \mu \mathrm{L}$ aliquots. The air-dried disks were applied directly onto the plates. The plates were incubated at $30^{\circ} \mathrm{C}$ for $48 \mathrm{~h}$, and the zones of inhibition were measured and compared between those on histidine-minus and histidine plates. The yeast strain carrying both pLexA-RAS ${ }^{\mathrm{V} 12}$ and pVP16-RAF (strain LZ) will be to grown on the SD-(His ${ }^{-}$) plate and allowed to express $\beta$-galactosidase. Ilimaquinone and geldanamycin were employed as positive controls. Active compounds were then tested at lower concentrations (20-2.5 $\mu \mathrm{g}$ per disk). The assays were performed in triplicate.

\section{$\beta$-Galactosidase assay}

$\beta$-Galactosidase activity was assayed according to the literature with modifications. ${ }^{7}$ One $\mathrm{mL}$ culture strains was taken at $\mathrm{A}_{600}$ between 0.50-1.00 and mixed with $20 \mu \mathrm{L}$ test compounds. The mixture was kept at $30{ }^{\circ} \mathrm{C}$ for $2 \mathrm{~h}$ and was harvested by centrifugation in a microfuge tube. Yeast pellets were resuspended in $0.7 \mathrm{~mL}$ of $\mathrm{Z}$ buffer (60 mmol L-1 $\mathrm{Na}_{2} \mathrm{HPO}_{4} \cdot 7 \mathrm{H}_{2} \mathrm{O}, 40 \mathrm{mmol} \mathrm{L}-1 \mathrm{NaH}_{2} \mathrm{PO}_{4} \cdot \mathrm{H}_{2} \mathrm{O}$, $10 \mathrm{mmol} \mathrm{L}^{-1} \mathrm{KCl}, 1 \mathrm{mmol} \mathrm{L} \mathrm{MgSO}_{4} \cdot 7 \mathrm{H}_{2} \mathrm{O}, 2.7 \mu \mathrm{L} \mathrm{mL}^{-1}$ $\beta$-mercaptoethanol), and followed by adding $20 \mu \mathrm{L}$ of freshly prepared $0.1 \%$ SDS and $50 \mu \mathrm{L}$ of chloroform into a microfuge tube with vortexing for 15 seconds. At time zero, the assay is initiated by adding $160 \mu \mathrm{L}$ of $4 \mathrm{mg} \mathrm{mL}^{-1}$ 2-nitrophenyl- $\beta$-D-galactopyranoside to each microfuge tube. After $20-60 \mathrm{~min}$ at $30{ }^{\circ} \mathrm{C}$, the reactions were terminated by the addition of $0.4 \mathrm{~mL}$ of $1 \mathrm{~mol} \mathrm{~L}^{-1} \mathrm{Na}_{2} \mathrm{CO}_{3}$ and the liberated $p$-nitrophenol was measured at $\mathrm{A}_{420} \mathrm{~nm}$. The $\beta$-galactosidase activity expressed in Miller Units (MU) which is calculated with formula below:

Miller Unit $=\left(\mathrm{A}_{420} \times 1000\right) /\left(\mathrm{A}_{600} \times \mathrm{t} \times \mathrm{V}\right)$

$\mathrm{t}=$ reaction time (minutes) $\mathrm{V}=$ reaction volume in $\mathrm{mL}$, equals to 1 if there is no dilution of cells.

Cells treated with extracts with less than $1 / 2$ MU of the control cells are scored as positive. ${ }^{7}$

\section{Results and Discussion}

Streptomyces sp. $\mathrm{H} 7372$ was cultured in liquid medium for seven days and the fermentation broth was extracted 
with $n$-BuOH. The extract was suspended in water, and then partitioned successively with $\mathrm{CHCl}_{3}$ and EtOAc to obtain the $\mathrm{CHCl}_{3}$ and EtOAc fractions. These fractions exhibited zones of inhibition on yeast two-hybrid screening which were subjected to repeated column chromatography and followed by semi-preparative HPLC separation to afford three new amides (1-3) along with thirteen known compounds; actiphenol (4), ${ }^{8} \mathrm{AH}-135 \mathrm{Y}(\mathbf{5}),{ }^{9}$ cycloheximide (6), ${ }^{10} \alpha$-epicycloheximide (7), ${ }^{11}$ cyclo $(\Delta$ Ala-L-Val $)(8),{ }^{12}$ cyclo(L-Pro-L-Val) (9), ${ }^{12}$ cyclo(L-Pro-L-Phe) $(\mathbf{1 0}),{ }^{13}$ cyclo(L-Pro-L-Trp) (11), ${ }^{14}$ cyclo(L-Trp-L-Phe) (12), ${ }^{15}$ cyclo(L-Trp-L-Tyr) (13), ${ }^{16}$ and cyclo(L-Phe-L-Leu) (14). ${ }^{17}$ The structures of the isolated compounds (Figure 1) were determined by the analysis of 1D- and 2D-NMR, mass spectral information and comparison with reported physical and spectroscopic data.

Compound 1 was isolated as a colorless viscous oil with the molecular formula $\mathrm{C}_{16} \mathrm{H}_{21} \mathrm{NO}_{5}$, determined from HRESIMS ( $\mathrm{m} / \mathrm{z} 308.1501[\mathrm{M}+\mathrm{H}]^{+}$, calc. 308.1498), indicating seven degrees of unsaturation. The IR spectrum indicated the presence of $\mathrm{OH}\left(3450 \mathrm{~cm}^{-1}\right)$ and carbonyl $\left(1645 \mathrm{~cm}^{-1}\right)$ functionalities. The UV spectrum showed maxima absorptions at $\lambda_{\max } 207,262$, and $348 \mathrm{~nm}$, which indicated the presence of a conjugated carbonyl-containing chromophore in the structure. The ${ }^{13} \mathrm{C}$ NMR and DEPT spectra (Table 1) displayed 16 resolved signals, which were classified into three methyl $\left(\delta_{\mathrm{C}} 51.7,20.5\right.$, and 15.4), three methylene $\left(\delta_{\mathrm{C}} 41.6,39.2\right.$, and 37.6), three methine $\left(\delta_{\mathrm{C}} 138.7,127.7\right.$, and 29.0$)$, four quaternary $\left(\delta_{\mathrm{C}} 158.9\right.$, $127.2,127.4$, and 118.3), one ketone-carbonyl $\left(\delta_{\mathrm{C}} 205.2\right)$, and two ester-carbonyl $\left(\delta_{C} 173.6\right.$, and 172.9) carbons. Three carbonyls from the ${ }^{13} \mathrm{C}$ NMR spectra accounted for three degrees of unsaturation, and the remaining four degrees of unsaturation required the presence of an aromatic ring in $\mathbf{1}$. The ${ }^{1} \mathrm{H}$ NMR spectrum of $\mathbf{1}$ (Table 1) displayed two singlet signals at $\delta 2.28(3 \mathrm{H}-15)$ and $2.22(3 \mathrm{H}-14)$, attributable to aromatic methyl groups, while meta-coupling aromatic protons at $\delta 7.46(1 \mathrm{H}, \mathrm{br} \mathrm{s}, \mathrm{H}-5)$ and $7.18(1 \mathrm{H}, \mathrm{br} \mathrm{s}, \mathrm{H}-3)$<smiles>COC(=O)CC(CC(N)=O)CC(=O)c1cc([N+](=O)[O-])cc(C)c1O</smiles><smiles>C[C@H]1C[C@H](C)C[C](C(O)CC2CC(=O)NC(=O)C2)C1=O</smiles>

6; $7 R$
7; $7 S$<smiles>Cc1cc(C)c(O)c(C(O)C2OC(=O)CC2CC(N)=O)c1</smiles>

2<smiles>C=C1NC(=O)[C@H](C(C)C)NC1=O</smiles>

8<smiles>[R]c1cc(C)cc(C(=O)CC2CC(=O)NC(=O)C2)c1OCC</smiles>

3; $R^{1}=\beta$-glucose, $R^{2}=M e$

4; $\mathrm{R}^{1}=\mathrm{H}, \mathrm{R}^{2}=\mathrm{Me}$ 5; $\mathrm{R}^{1}=\mathrm{H}, \mathrm{R}^{2}=\mathrm{CH}_{2} \mathrm{OH}$
9; $R^{1}=R^{2}=M e$
10; $R^{1}=H ; R^{2}=P h$
11; $R^{1}=H, R^{2}=3$-indole<smiles>[R]c1ccc(CC2NC(=O)[C@H](Cc3c[nH]c4ccccc34)NC2=O)cc1</smiles>

12; $\mathrm{R}=\mathrm{H}$

13; $\mathrm{R}=\mathrm{OH}$<smiles>CC(C)C[C@@H]1NC(=O)[C@H](Cc2ccccc2)NC1=O</smiles>

14

Figure 1. Structures of the isolated compounds (1-14). 
Table 1. ${ }^{1} \mathrm{H}(500 \mathrm{MHz})$ and ${ }^{13} \mathrm{C}(125 \mathrm{MHz})$ NMR Assignments of compounds $\mathbf{1 - 3}$ in $\mathrm{CD}_{3} \mathrm{OD}(\delta$, mult, $J$ in $\mathrm{Hz})$

\begin{tabular}{|c|c|c|c|c|c|c|}
\hline \multirow[t]{2}{*}{ Position } & \multicolumn{2}{|r|}{$\mathbf{1}^{\mathrm{a}}$} & \multicolumn{2}{|r|}{2} & \multicolumn{2}{|r|}{3} \\
\hline & $\delta_{\mathrm{C}}$ & $\delta_{\mathrm{H}}$ & $\delta_{\mathrm{C}}$ & $\delta_{\mathrm{H}}$ & $\delta_{\mathrm{C}}$ & $\delta_{\mathrm{H}}$ \\
\hline 1 & 158.9 & & 151.7 & & 151.3 & \\
\hline 2 & 127.2 & & 126.6 & & 137.7 & \\
\hline 3 & 138.7 & $7.18 \mathrm{br} \mathrm{s}$ & 131.8 & $6.84 \mathrm{br} \mathrm{s}$ & 136.2 & $7.20 \mathrm{~d}(1.7)$ \\
\hline 4 & 127.4 & & 130.6 & & 133.4 & \\
\hline 5 & 127.7 & 7.46 br s & 129.9 & $6.99 \mathrm{br} \mathrm{s}$ & 127.2 & $7.01 \mathrm{~d}(1.7)$ \\
\hline 6 & 118.3 & & 128.2 & & 136.2 & \\
\hline 7 & 205.2 & & 72.1 & $5.22 \mathrm{~d}(3.2)$ & 207.6 & \\
\hline 8 & 41.6 & $3.18 \mathrm{~d}(6.6)$ & 88.2 & $4.58 \mathrm{dd}(4.8,3.2)$ & 48.4 & $\begin{array}{c}3.35 \mathrm{~m} \\
2.95 \mathrm{dd}(17.8,5.3)\end{array}$ \\
\hline 9 & 29.0 & 2.95 sept (6.6) & 32.6 & $2.94 \mathrm{~m}$ & 27.5 & $2.70 \mathrm{~m}$ \\
\hline 10 & 37.6 & $2.57 \mathrm{~d}(6.6)$ & 35.9 & $\begin{array}{l}2.70 \mathrm{dd}(18.0,9.8) \\
2.26 \mathrm{dd}(18.0,5.6)\end{array}$ & 38.0 & $\begin{array}{l}2.74 \mathrm{~m} \\
2.46 \mathrm{~m}\end{array}$ \\
\hline 11 & 172.9 & & 179.5 & & 175.0 & \\
\hline 12 & 39.2 & $2.40 \mathrm{~d}(6.6)$ & 40.2 & $\begin{array}{l}2.11 \mathrm{dd}(15.0,9.0) \\
2.06 \mathrm{dd}(15.0,5.5)\end{array}$ & 38.3 & $\begin{array}{l}2.70 \mathrm{~m} \\
2.37 \mathrm{~m}\end{array}$ \\
\hline 13 & 173.6 & & 175.9 & & 175.0 & \\
\hline 14 & 15.4 & $2.22 \mathrm{~s}$ & 16.3 & $2.15 \mathrm{~s}$ & 16.4 & $2.35 \mathrm{~s}$ \\
\hline 15 & 20.5 & $2.28 \mathrm{~s}$ & 20.7 & $2.20 \mathrm{~s}$ & 20.6 & $2.28 \mathrm{~s}$ \\
\hline $1^{\prime}$ & & & & & 105.8 & $4.35 \mathrm{~d}(7.8)$ \\
\hline $2^{\prime}$ & & & & & 75.4 & $3.46 \mathrm{dd}(9.3,7.8)$ \\
\hline $3^{\prime}$ & & & & & 77.8 & $3.36 \mathrm{t}(9.3)$ \\
\hline $4^{\prime}$ & & & & & 71.8 & 3.35 t (9.3) \\
\hline $5^{\prime}$ & & & & & 78.3 & $3.07 \mathrm{ddd}(9.3,6.7,2.3)$ \\
\hline $6^{\prime}$ & & & & & 63.0 & $\begin{array}{l}3.71 \mathrm{dd}(12.2,2.3) \\
3.60 \mathrm{dd}(12.2,6.7)\end{array}$ \\
\hline $\mathrm{OMe}$ & 51.7 & $3.69 \mathrm{~s}$ & & & & \\
\hline $\mathrm{NH}_{2}$ & & $5.84 \mathrm{~s}, 5.46 \mathrm{~s}$ & & & & \\
\hline
\end{tabular}

${ }^{\mathrm{a}}$ Recorded in $\mathrm{CDCl}_{3}$.

suggested the presence of 1,2,3,5-tetrasubstituted aromatic ring. The ${ }^{1} \mathrm{H}$ NMR and COSY spectra indicated that the methine at $\delta 2.95(1 \mathrm{H}$, sept, $J 6.6 \mathrm{~Hz}, \mathrm{H}-9)$, and three sets of methylene protons $\alpha$ to a carbonyl $[\delta 3.18(1 \mathrm{H}, \mathrm{d}$, $J 6.6 \mathrm{~Hz}, \mathrm{H}-8), 2.57(1 \mathrm{H}, \mathrm{d}, J 6.6 \mathrm{~Hz}, \mathrm{H}-10)$, and $2.40(1 \mathrm{H}$, d, $J 6.6 \mathrm{~Hz}, \mathrm{H}-12)$ ], were connected as a $-\mathrm{CH}_{2}-\mathrm{CH}-\left(\mathrm{CH}_{2}\right)_{2}$ unit. Additionally, two singlets at $\delta 5.84$, and 5.46 were assigned to $\mathrm{NH}_{2}$. The full ${ }^{1} \mathrm{H}$ and ${ }^{13} \mathrm{C}$ NMR spectroscopic assignments for $\mathbf{1}$ based on 2D-NMR experiments were closely related to those of phenatic acid $\mathrm{A},{ }^{8}$ except for the additional singlet signal of OMe group at $\delta 3.69$. The HMBC spectrum of 1 showed correlations from $3 \mathrm{H}-14$ to C-1, C-2, and C-3; $3 \mathrm{H}-15$ to C-3, C-4, and C-5; and H-5 to $\mathrm{C}-1, \mathrm{C}-3, \mathrm{C}-7$ and $\mathrm{C}-15$, confirming the assignments of substituted aromatic ring. The correlations of the $\mathrm{OMe}$ signal to C-11, of $2 \mathrm{H}-8$ to $\mathrm{C}-6, \mathrm{C}-7, \mathrm{C}-10$ and $\mathrm{C}-12$, of $2 \mathrm{H}-10$ to $\mathrm{C}-8, \mathrm{C}-9, \mathrm{C}-11$ and $\mathrm{C}-12$, and of $2 \mathrm{H}-12$ to $\mathrm{C}-8$,
C-9, C-10 and C-13 confirmed the structural assignments and the OMe group at $\mathrm{C}-11$. Therefore, compound $\mathbf{1}$ was determined to be methyl phenatate A.

Compound 2 was isolated as a colorless viscous oil and had a HRESIMS molecular ion peak at $m / z, 276.1232$ $\left[\mathrm{M}+\mathrm{H}-\mathrm{H}_{2} \mathrm{O}\right]^{+}$, which was compatible with the molecular formula $\mathrm{C}_{15} \mathrm{H}_{19} \mathrm{NO}_{5}$ (calc. 276.1230). The ${ }^{1} \mathrm{H}$ and ${ }^{13} \mathrm{C} \mathrm{NMR}$ spectra (Table 1) of $\mathbf{2}$ were comparable to those of $\mathbf{1}$, except for the differences in the aliphatic proton region. The presence of two oxymethine protons at $\delta 5.22(1 \mathrm{H}, \mathrm{d}$, $J 3.2 \mathrm{~Hz})$ and $4.58(1 \mathrm{H}, \mathrm{dd}, J 4.8,3.2 \mathrm{~Hz})$, and an aliphatic methine proton at $\delta 2.94(1 \mathrm{H}, \mathrm{m})$ were assigned to $\mathrm{H}-7$, H-8 and H-9, respectively. In addition, one AX system methylene protons was found at $\delta 2.70(1 \mathrm{H}, \mathrm{dd}, J 18.0$, $9.8 \mathrm{~Hz}, \mathrm{H}-10 \mathrm{a})$, and $2.26(1 \mathrm{H}, \mathrm{dd}, J 18.0,5.6 \mathrm{~Hz}, \mathrm{H}-10 \mathrm{~b})$ and another $\mathrm{AB}$ system of methylene protons was found at $\delta 2.11(1 \mathrm{H}, \mathrm{dd}, J 15.0,9.0 \mathrm{~Hz}, \mathrm{H}-12 \mathrm{a}), 2.06(1 \mathrm{H}$, dd, 
$J$ 15.0, 5.5 Hz, H-12b). The connectivity of H-7/H-8, $\mathrm{H}-8 / \mathrm{H}-9, \mathrm{H}-9 / \mathrm{H} 10$ and $\mathrm{H}-9 / \mathrm{H}-12$ in a COSY spectrum confirmed the assignments. In the HMBC experiments, the oxymethine proton $\mathrm{H}-8$ correlated with the C-6, C-9, C-10, $\mathrm{C}-11$, and $\mathrm{C}-12$, and confirmed the attachment of a lactone ring at C-8. The small coupling constant of $\mathrm{H}-8(\mathrm{~J} 4.8 \mathrm{~Hz})$ and cross-peaks between $\mathrm{H}-8 / \mathrm{H}-9$ and $\mathrm{H}-7 / 2 \mathrm{H}-10$ from ROESY experiments indicated that $\mathrm{H}-8$ and $\mathrm{H}-9$ were in a cis-orientation. Thus, compound $\mathbf{2}$ was determined to be actiphenamide.

Compound $\mathbf{3}$, isolated as a colorless viscous oil, had the molecular ion $[\mathrm{M}+\mathrm{H}+\mathrm{Na}]^{+}$whose mass as determined by HRESIMS was $m / z 461.1629$, calcd for $\mathrm{C}_{21} \mathrm{H}_{27} \mathrm{NO}_{9}$. The ${ }^{1} \mathrm{H}$ NMR data (Table 1) displayed a characteristics of a glutarimide ring ${ }^{9}$ at $\delta 2.74(1 \mathrm{H}, \mathrm{m}, \mathrm{H}-10 \mathrm{a}), 2.70(2 \mathrm{H}, \mathrm{m}, \mathrm{H}-9$ and $\mathrm{H}-12 \mathrm{a}), 2.46(1 \mathrm{H}, \mathrm{m}, \mathrm{H}-10 \mathrm{~b})$ and $2.37(1 \mathrm{H}, \mathrm{m}, \mathrm{H}-12 \mathrm{~b})$. A methine proton at $\delta 2.70(\mathrm{H}-9)$ also showed crosspeaks with the methylene protons at $\delta 3.35(1 \mathrm{H}, \mathrm{m}, \mathrm{H}-8 \mathrm{a})$ and $2.95(1 \mathrm{H}, \mathrm{dd}, J 17.8,5.3 \mathrm{~Hz}, \mathrm{H}-8 \mathrm{~b})$ from the COSY experiments. The remaining resonances observed in the ${ }^{1} \mathrm{H}$ and ${ }^{13} \mathrm{C}$ NMR spectra of $\mathbf{3}$ were attributable to a glycosyl unit. The ${ }^{1} \mathrm{H}$ and ${ }^{13} \mathrm{C}$ NMR spectroscopic data (Table 1) displayed resonances characteristic for a glycosyl moiety containing five oxymethine groups at $\delta_{\mathrm{H}} / \delta_{\mathrm{C}} 4.35 / 105.8$ (H-1'/C-1'), 3.46/75.4 (H-2'/C-2'), 3.36/77.8 (H-3'/C-3'), $3.35 / 71.8\left(\mathrm{H}-4^{\prime} / \mathrm{C}-4^{\prime}\right)$, and 3.07/78.3 (H-5'/C-5') and one set of oxymethylene protons at $\delta_{\mathrm{H}} / \delta_{\mathrm{C}} 3.71,3.60 / 63.0$ (2H-6'/C-6'). This unit was attached to 1-hydroxy-2,4dimethylbenzene ring at $\mathrm{C}-1$, as determined by an HMBC correlation from $\mathrm{H}-1^{\prime}$ to $\mathrm{C}-1$. The vicinal coupling constants, $J_{1^{\prime}, 2^{\prime}}, 8.8 \mathrm{~Hz}, J_{2^{\prime}, 3^{\prime}} 9.3 \mathrm{~Hz}$ and $J_{4^{\prime} 5^{\prime}} 9.3 \mathrm{~Hz}$, suggested that $\mathrm{H}-\mathrm{1}^{\prime}, \mathrm{H}-2^{\prime}, \mathrm{H}-3^{\prime}, \mathrm{H}-4^{\prime}$ and $\mathrm{H}-5^{\prime}$ were axial in orientation in the pyranose ring. NOESY cross signals observed from $\mathrm{H}-1^{\prime}$ to $\mathrm{H}-3^{\prime}$ and from $\mathrm{H}-1^{\prime}$ to $\mathrm{H}-5^{\prime}$ confirmed that a sugar unit of $\mathbf{3}$ was $\beta$-D-glucopyranose. Thus, compound $\mathbf{3}$ was identified as actiphenol 1- $\beta$-D-glucopyranoside.

All isolates were evaluated for their inhibitory activities of Ras-Raf-1 interaction in the yeast two-hybrid assay (Table 2) according to a literature method. ${ }^{3}$ In brief, we looked for a compound giving a clear zone of inhibition (ZOI) that inhibited growth of LZ cells in the SD His ${ }^{-}$plates and not in the SD His ${ }^{+}$plates, together with inhibition of $\beta$-galactosidase activity. This would indicate the compound is an inhibitor of Ras-Raf-1 interaction. Compounds 6 and 8 showed high potency with 10 and $25 \mathrm{~mm}$ clear ZOIs on SD His ${ }^{-}$and inactive on SD His ${ }^{+}$at $2.5 \mu \mathrm{g} \mathrm{per}$ disk, respectively, whereas all other compounds 1-5, 7, 9-14 were inactive. In addition, both compounds gave a clear ZOI that inhibited growth of LZ cells in the SD His ${ }^{-}$ plates and not in the SD $\mathrm{His}^{+}$plates, and together with inhibition of $\beta$-galactosidase activity, indicated $\mathbf{6}$ and $\mathbf{8}$ were inhibitors of Ras-Raf-1 interaction. The potency of these compounds was comparable to that of doxorubicin and geldanamycin but higher than those of the positive controls. Cycloheximide (6) showed the strongest activity against $\beta$-galactosidase with $79.8 \%$ inhibition of $\beta$-galactosidase activity whereas cyclo( $\Delta$ Ala-L-Val) $(8)$ exhibited a weaker effect $(62.7 \%)$. Geldanamycin, a heat shock protein 90 (HSP90) inhibitor and ilimaquinone were employed as positive controls and gave $82.3 \%$, and $96.1 \%$ inhibition of $\beta$-galactosidase activity, respectively. Ilimaquinone, previously isolated from the marine sponge Hippospongia metachromia, inhibited tyrosine kinase activity by $87 \%$ at a concentration of $1 \mu \mathrm{g} \mu \mathrm{L}^{-1}{ }^{18}$ Cycloheximide (6) was isolated from the cultures of Streptomyces griseus and has been demonstrated to inhibit protein synthesis in mammalian systems. ${ }^{3,19} \mathrm{AH}-135 \mathrm{Y}$ (5) has been reported from Streptomyces albovinaceus is reported to have antiherpetic, cytotoxic and antifungal activities. ${ }^{9}$

Many terrestrial yeast, lichens, and fungi are known to produce diketopiperazines by condensation of two amino acids. Natural diketopiperazines show a remarkable preference for proline as a building block. ${ }^{20}$ They consist mostly of two L-amino acids, but DL-, LD-, and DD-isomers can be generated by non-enzymatic epimerization, possibly accelerated by steric effects. ${ }^{21}$ In the literature there are two report of DD-enantiomers of diketopiperazines as natural compounds. ${ }^{22,23}$ The DD-enantiomers exhibited

Table 2. Yeast two-hybrid screening of compounds 6 and 8

\begin{tabular}{|c|c|c|c|c|c|c|c|c|c|c|}
\hline \multirow[t]{3}{*}{ Compounds } & \multicolumn{4}{|c|}{ Ras-Raf-1 assay ( $\mu \mathrm{g}$ per disk) } & \multicolumn{4}{|c|}{ Ras-Raf-1 assay ( $\mu \mathrm{g}$ per disk) } & \multirow{3}{*}{\multicolumn{2}{|c|}{$\begin{array}{c}{ }^{b} \beta \text {-galactosidase } \\
\text { activity at } 80 \mu \mathrm{g} \text { per } 20 \mu \mathrm{I} \\
\mathrm{MU}(\mathrm{n}=2)\end{array}$}} \\
\hline & 20 & 10 & 5 & 2.5 & 20 & 10 & 5 & 2.5 & & \\
\hline & \multicolumn{4}{|c|}{$(\mathrm{mm})\left(\mathrm{SD} \mathrm{His}^{-}\right)$} & \multicolumn{4}{|c|}{$(\mathrm{mm})\left(\mathrm{SD} \mathrm{His}^{+}\right)$} & & \\
\hline Cycloheximide (6) & 20 & 16 & 13 & 10 & na & na & na & na & 4.68 & $79.8 \%$ \\
\hline $\operatorname{Cyclo}(\Delta$ Ala-L-Val $)(\mathbf{8})$ & 35 & 30 & 27 & 25 & na & na & na & na & 8.66 & $62.7 \%$ \\
\hline Doxorubicin & 14 & 10 & 8 & na & 10 & 8 & na & na & 11.70 & $50.0 \%$ \\
\hline Geldanamycin & 9 & 8 & na & na & na & na & na & na & 4.17 & $82.3 \%$ \\
\hline Ilimaquinone $^{a}$ & na & na & na & na & na & na & na & na & 0.84 & $96.1 \%$ \\
\hline
\end{tabular}

${ }^{a}$ Ilimaquinone gave $11 \mathrm{~mm}$ zone of inhibition on SD His ${ }^{-}$but not on SD His ${ }^{+}$at $80 \mu \mathrm{g}$ per disk. na indicates not active. 
potent inhibitory activity against the pathogen Vibrio anguillarum, ${ }^{23}$ whereas LL-enantiomers as well as cyclo-(LLeu-L-Pro), cyclo-(L-Phe-L-Pro), and cyclo-(L-Trp-L-Pro) isolated from a deep sea bacterium exhibited antilarval activity. ${ }^{24}$ Interestingly, the dehydro-ketopiperazines, cyclo( $\triangle$ Ala-L-Val) $(\mathbf{8})$ was recently been reported to be produced by Pseudomonas aeruginosa and act as a new signal ligand in bacterial quorum sensing ${ }^{12}$. Furthermore, the dehydro-ketopiperazines are known to be mammalian cell cycle inhibitor ${ }^{25}$ as such this compound (8) deserved to be further investigated for its mode of action and application.

\section{Supplementary Information}

The ${ }^{1} \mathrm{H}$ and ${ }^{13} \mathrm{C}$ NMR of 1-3 are available free of charge at http://jbcs.sbq.org.br as PDF file.

\section{Acknowledgments}

We would like to thank W. Niemczura and W. Yoshida (University of Hawaii Manoa Chemistry Department NMR Facility) for assistance with Varian Unity Inova $500 \mathrm{MHz}$ NMR measurements, and P. William (University of Hawaii Manoa Chemistry Department) for technical assistance with mass spectra. We are grateful to D. Horgen (Hawaii Pacific University) for NMR and mass spectra. We thank M. Yoshida (Tokyo University), J. Cooper (University of Washington at Seattle), S. W. Ki and S. Lal for help in the yeast two-hybrid system. Financial support from the Start-up fund from College of Pharmacy, UH Hilo (to L. C. C). This work was also supported by a grant in UMS (to H.C.C).

\section{References}

1. Cohen, P.; Nat. Rev. Drug Discovery 2002, 1, 309.

2. Wipf, P.; Chem. Rev. 1995, 95, 2115.

3. Ki, S. W.; Kasahara, K.; Kwon, H. J.; Eishima, J.; Takesako, K.; Cooper, J. A.; Yoshida, M.; Horinouchi, S.; J. Antibiot. 1998, $51,936$.

4. Omura, S.; Iwai, Y.; Hirano, A.; Nakagawa, A.; Awaya, J.; Tsuchiya, H.; Takahashi, Y.; Masuma, R.; J. Antibiot. 1977, $30,275$.
5. Cheah, H. Y.; MSc Dissertation, University Malaysia Sabah, Malaysia, 2003.

6. Nonomura, H.; Hayakawa, M. In Biology of Actinomycetes'88; Okami, Y.; Beppu, T.; Ogawara, H., eds.; Japan Scientific Societies Press: Tokyo, 1988, pp. 288-293.

7. Zhang, X.; Bremer, H.; J. Biol. Chem. 1995, $270,11181$.

8. Fukuda, T.; Matsumoto, A.; Takahashi, Y.; Tomoda, H.; Omura, S.; J. Antibiot. 2005, 58, 252.

9. Uyeda, M.; Aoki, M.; Nakajima, K.; Shiromoto, C.; Tatsuguchi, N.; Yokomizo, K.; Kido, Y.; Kino, Y.; J. Antibiot. 1992, 45, 1370.

10. Jeffs, P.; McWilliams, D.; J. Am. Chem. Soc. 1981, 103, 6185.

11. Johnson, F.; Carlson, A. A.; Tetrahedron Lett. 1965, 6, 885.

12. Holden, M. T. G.; Chhabra, S. R.; de Nys, R.; Stead, P.; Bainton, N. J.; Hill, P. J.; Manefield, M.; Kumar, N.; Labatte, M.; England, D.; Rice, S.; Givskov, M.; Salmond, G. P. C.; Stewart, G. S. A. B.; Bycroft, B. W.; Kjelleberg, S.; Williams, P.; Mol. Microbiol. 1999, 33, 1254.

13. Jayatilake, G. S.; Thornton, M. P.; Leonard, A. C.; Grimwade, J. E.; Baker, B. J.; J. Nat. Prod. 1996, 59, 293.

14. Wang, F.; Fang, Y.; Zhu, T.; Zhang, M.; Lin, A.; Gu, Q.; Zhu, W.; Tetrahedron 2008, 64, 7986.

15. Kimura, Y.; Tani, K.; Kojima, A.; Sotoma, G.; Okada, K.; Shimada, A.; Phytochemistry 1996, 41, 665.

16. Grundmann, A.; Li, S. -M.; Microbiology 2005, 151, 2199.

17. Kanzaki, H.; Imura, D.; Nitoda, T.; Kawazu, K.; J. Mol. Catal. B: Enzym. 1999, 6, 265.

18. Wessels, M.; König, G. M.; Wright, A. D.; J. Nat. Prod. 1999, 62, 927.

19. Ennis, H. L.; Lubin, M.; Science 1964, 146, 1474.

20. Bull, S. D.; Davies, S. G.; Parkin, R. M.; Sánchez-Sancho, F.; J. Chem. Soc., Perkin Trans. 1 1998, 2313.

21. Smith, G. G.; Evans, R. C.; Baum, R.; J. Am. Chem. Soc. 1986, $108,7327$.

22. Adamczeski, M.; Reed, A. R.; Crew, P.; J. Nat. Prod. 1995, 58, 201.

23. Fdhila, F.; Vazquez, V.; Sanchez, J. L.; Riguera, R.; J. Nat. Prod. 2003, 66, 1299.

24. Li, X.; Dobretsov, S. ; Xu, Y.; Xiao, X.; Hung, O. S.; Qian, P.-Y.; Biofouling 2006, 22, 187.

25. O'Neill, J. C. ; Blackwell, H. E.; Comb. Chem. High Throughput Screening 2007, 10, 857.

Received: January 7, 2010

Web Release Date: September 21, 2010 


\section{Three New Amides from Streptomyces sp. $\mathbf{H 7 3 7 2}$}

Sarot Cheenpracha, ${ }^{a}$ Robert P. Borris, ${ }^{a}$ Tammy T. Tran, ${ }^{a}$ Jap Meng Jee, ${ }^{b}$ Heng Fong Seow, ${ }^{b}$ Hwen-Yee Cheah, ${ }^{b}$ Coy Choke Ho ${ }^{c}$ and Leng Chee Chang ${ }^{*, a}$

${ }^{a}$ Department of Pharmaceutical Sciences, College of Pharmacy, University of Hawaii Hilo, 34 Rainbow Drive, 96720 Hilo, HI, USA

${ }^{b}$ Immunology Unit, Department of Pathology, Faculty of Medicine and Health Sciences, Universiti Putra Malaysia, 43400 Serdang, Selangor, Malaysia

'Biotechnology Program, School of Science and Technology, University Malaysia Sabah, 88999 Kota Kinabalu, Sabah, Malaysia

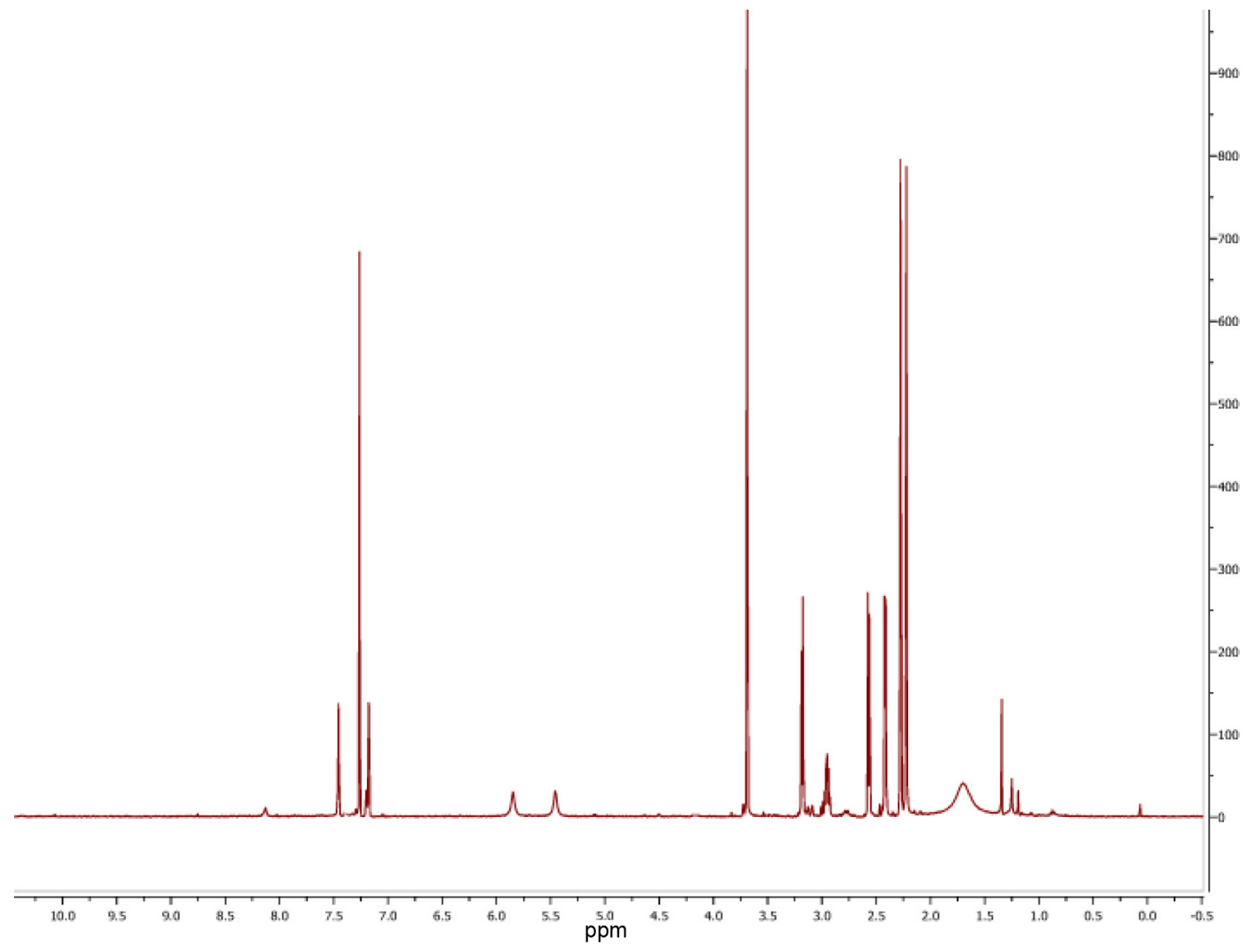

Figure S1. ${ }^{1} \mathrm{H}$ NMR spectrum of compound $1\left(500 \mathrm{MHz}, \mathrm{CDCl}_{3}\right)$. 


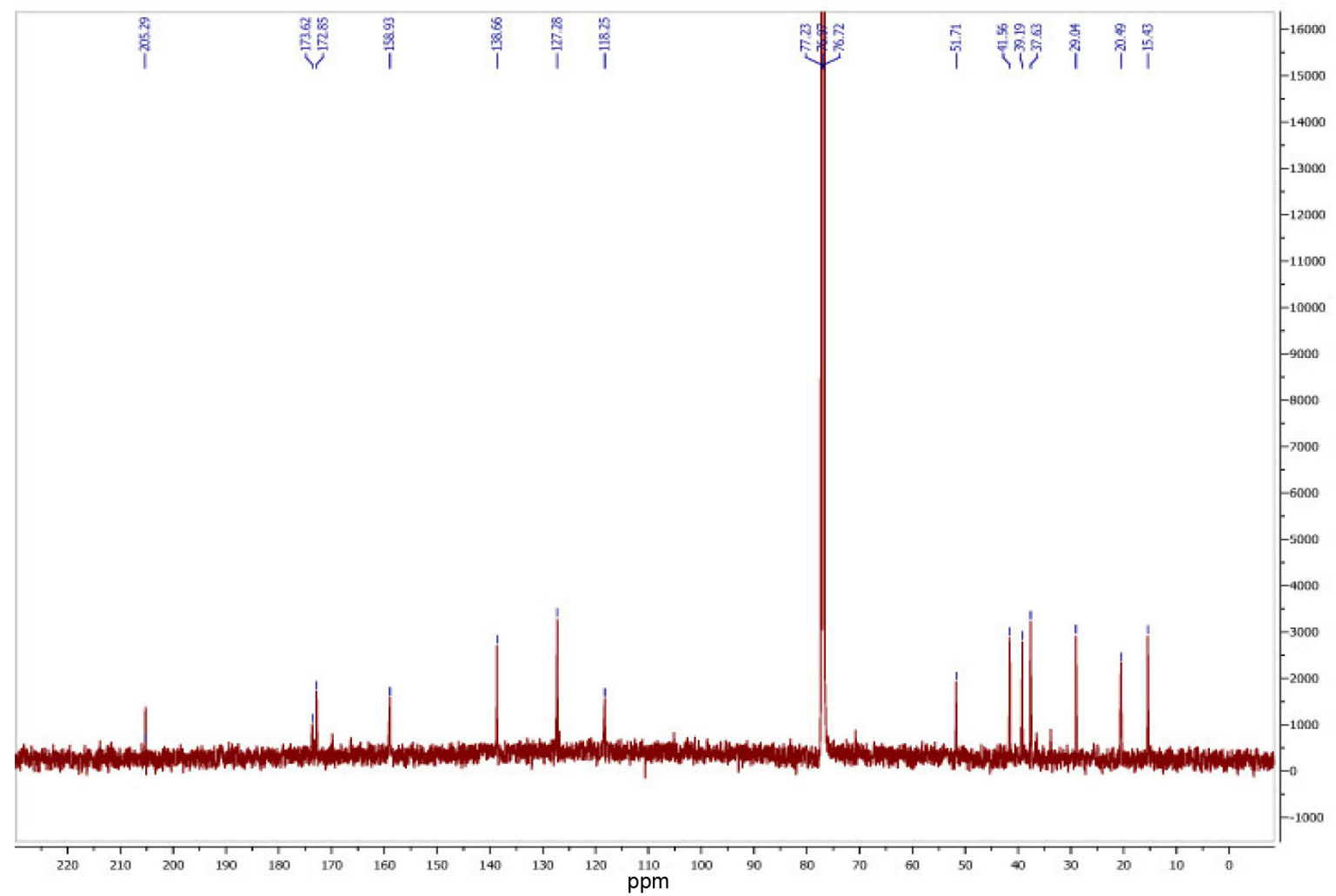

Figure S2. ${ }^{13} \mathrm{C}$ NMR spectrum of compound $\mathbf{1}\left(125 \mathrm{MHz}, \mathrm{CDCl}_{3}\right)$.

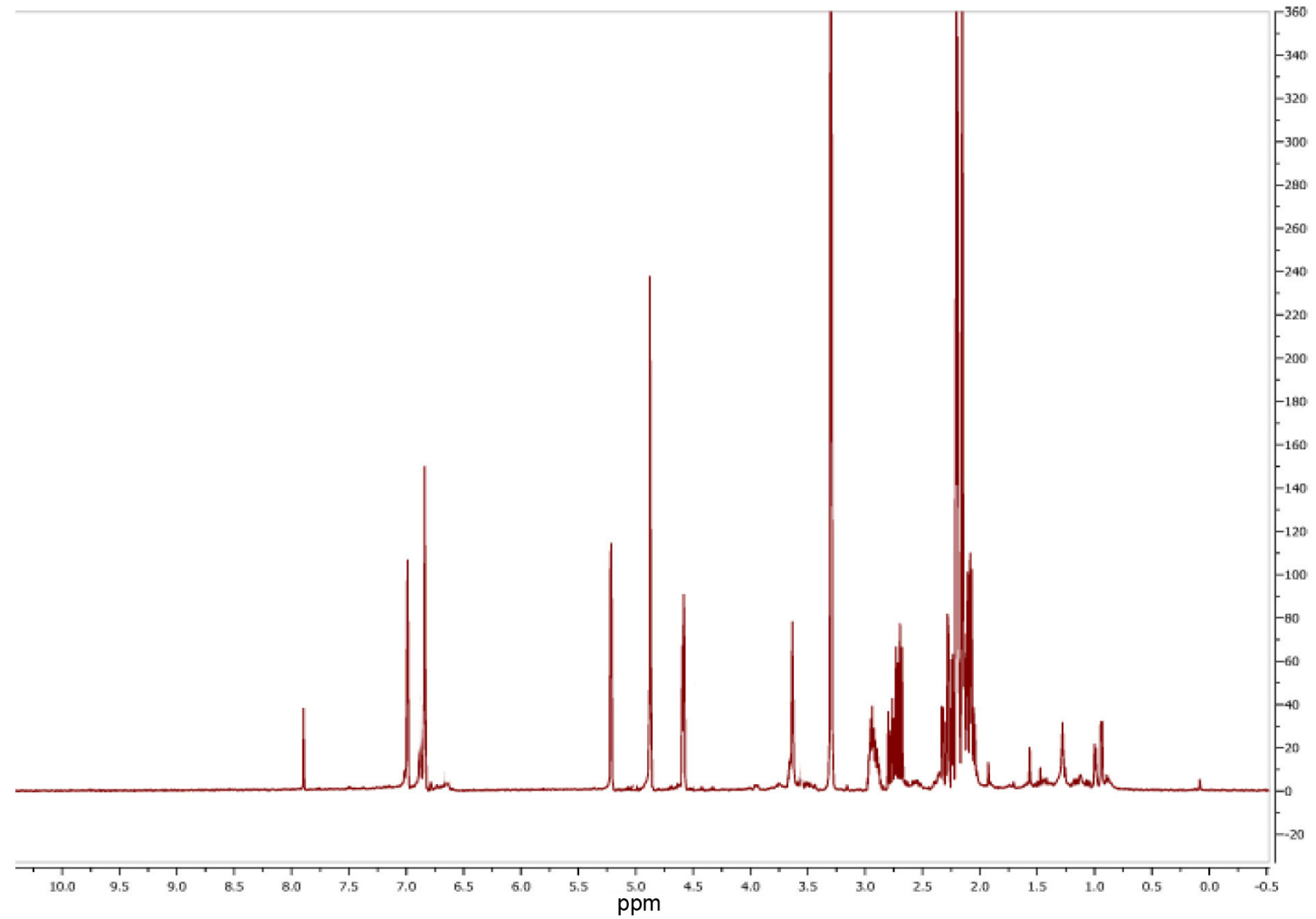

Figure S3. ${ }^{1} \mathrm{H}$ NMR spectrum of compound $2\left(500 \mathrm{MHz}, \mathrm{CD}_{3} \mathrm{OD}\right)$. 


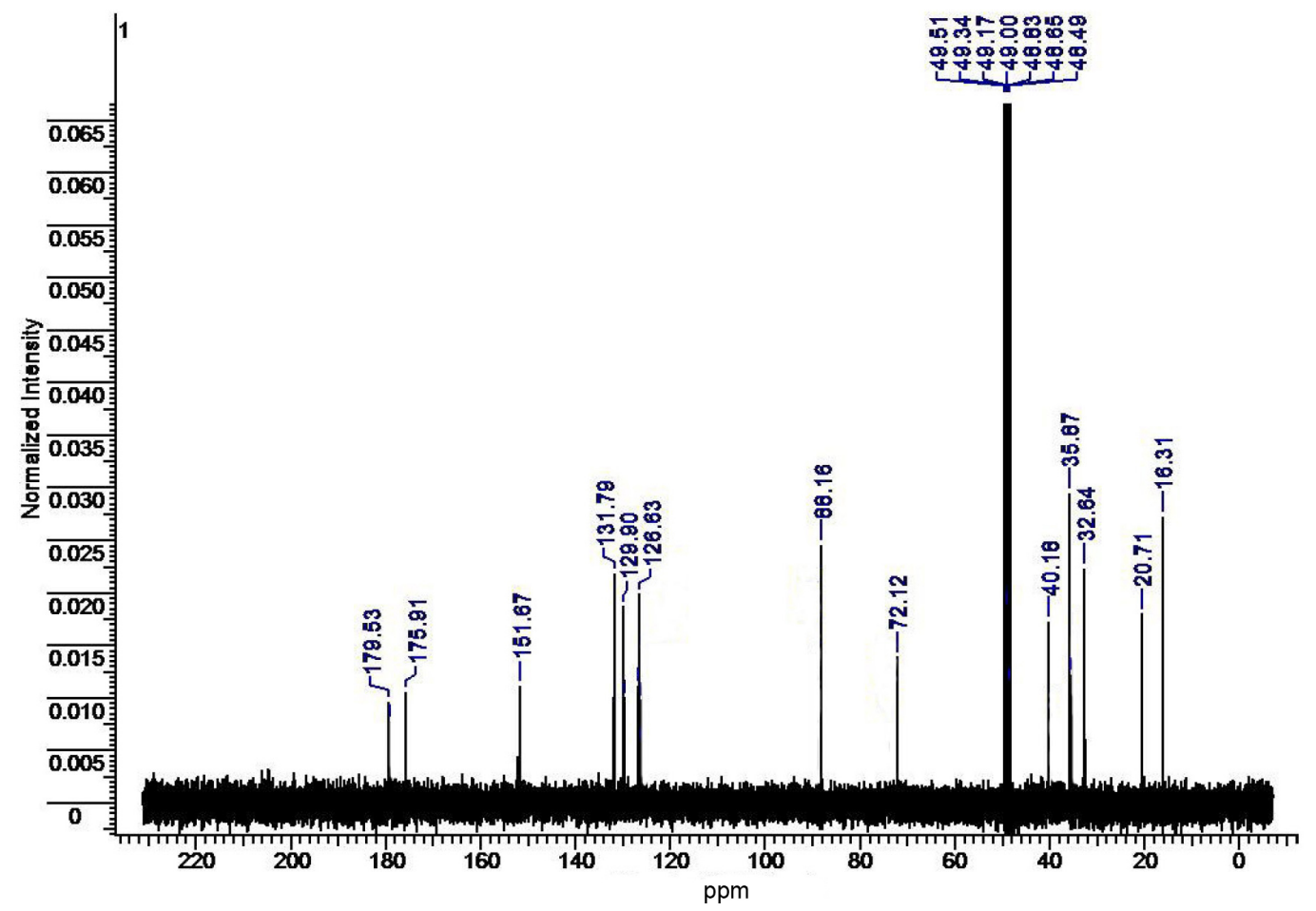

Figure S4. ${ }^{13} \mathrm{C}$ NMR spectrum of compound $2\left(125 \mathrm{MHz}, \mathrm{CD}_{3} \mathrm{OD}\right)$.

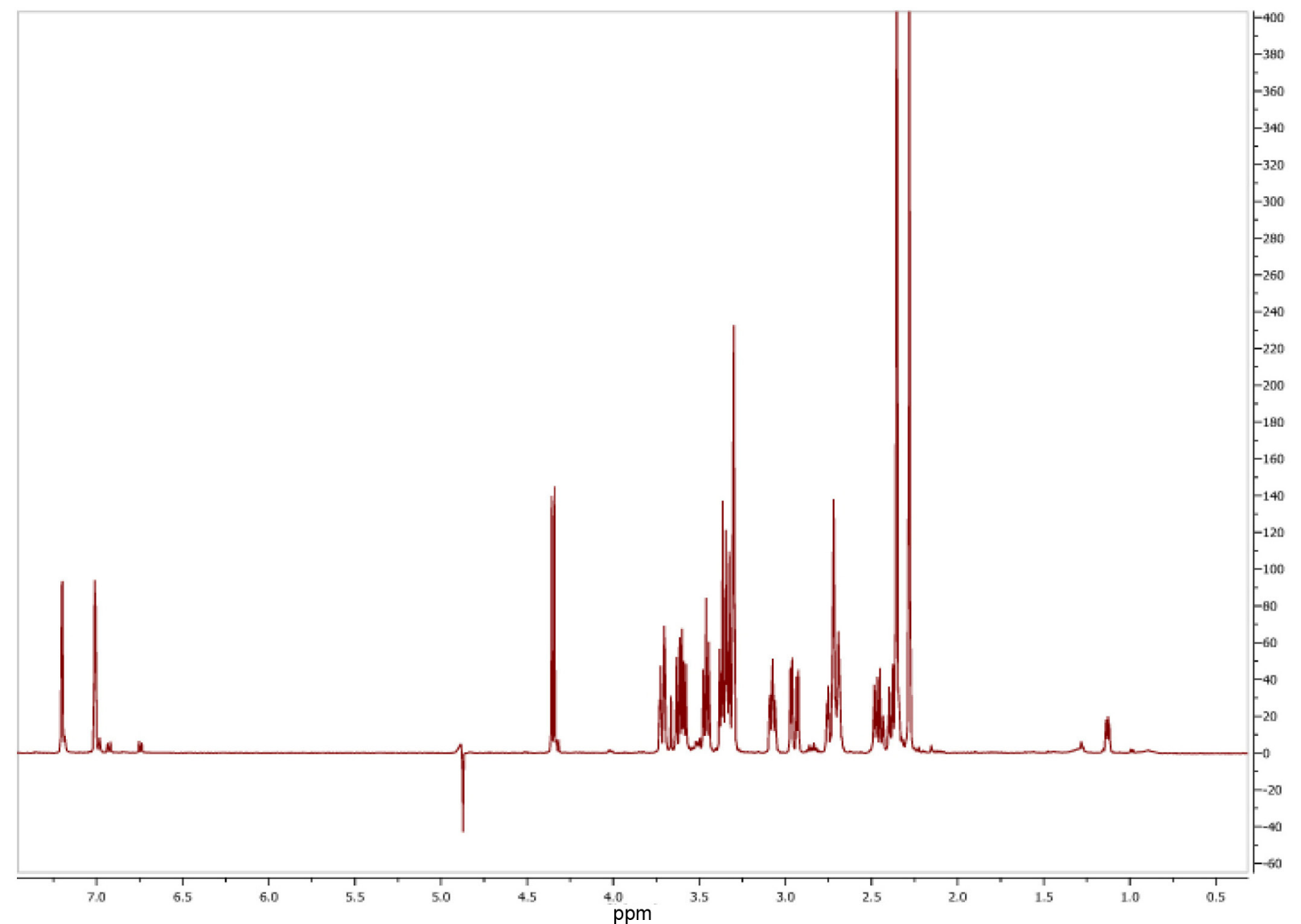

Figure S5. ${ }^{1} \mathrm{H}$ NMR spectrum of compound $3\left(125 \mathrm{MHz}, \mathrm{CD}_{3} \mathrm{OD}\right)$. 
SH

Three New Amides from Streptomyces sp. H7372

J. Braz. Chem. Soc.

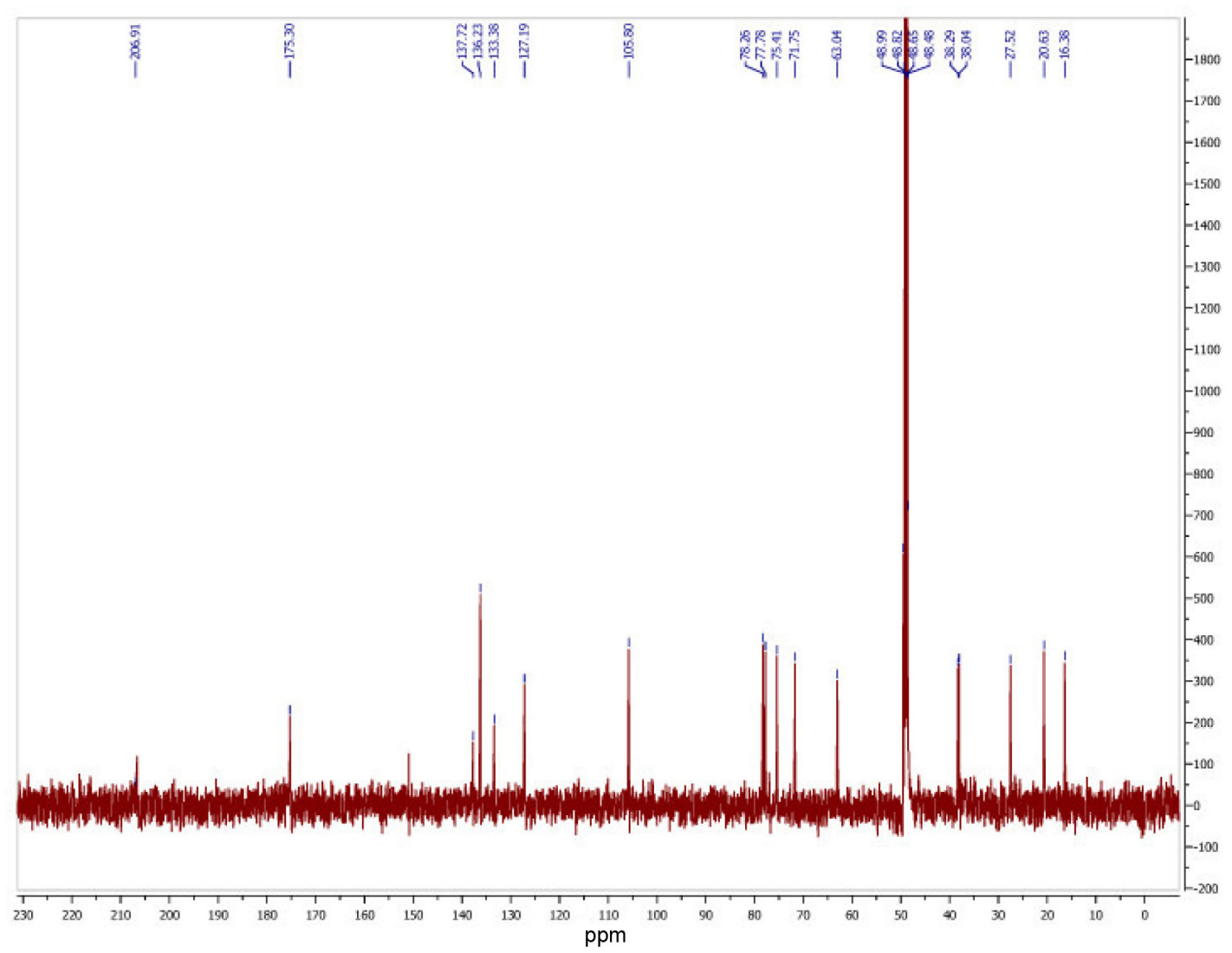

Figure S6. ${ }^{13} \mathrm{C}$ NMR spectrum of compound $3\left(125 \mathrm{MHz}, \mathrm{CD}_{3} \mathrm{OD}\right)$ 